\title{
After Privatisation: Economic Development, Social Transformation and Corporate Governance in the Baltic States
}

\author{
Antti Ainamo / William Cardwell ${ }^{* *}$
}

The general problem in emerging economies is that there is no well-defined system that supports a balanced relationship between management and other stakeholders of the firm. This paper describes how emerging systems of corporate governance in the Baltic States have interacted with economic development and social transformation, and how after privatisation foundations for such a system of corporate governance are beginning to take root. We identify some sub-systems of corporate governance that have emerged in the Baltic States: a local stabilising force, a working legal framework, and precedent cases of rules of the game. These sub-systems, and their order of appearance, may be generalisable to other immature, emerging or developing economies.

Ein generelles Problem in den Transformationsländern besteht im Fehlen eines klar definierten Systems zur Regelung der Beziehungen zwischen dem Management und anderen betrieblichen Interessengruppen. Dieser Artikel beschreibt die Interaktion entstehender Systeme der Betriebsführung mit der ökonomischen und sozialen Entwicklung in den Baltischen Ländern. Es werden Subsysteme der Unternehmensführung (eine lokal stabilisierende Kraft; ein funktionsfähiges Rechtssystem; Präzedenzfälle bezüglich der Spielregeln) identifiziert. Diese lassen sich vermutlich, auch in der Reihenfolge ihres Erscheinens, auf andere Transformationsländer übertragen.

Manuscript received 20.10.96, accepted 13.11.97

** Antti Ainamo, born 1963, Ph.D., Helsinki School of Economics and Business Administration, Department of Management / The Academy of Finland. Major areas of research interest: product design and development, management, innovation and learning.

Will Cardwell, born 1963, MBA (Helsinki School of Economics), Director, Finance Institute at Helsinki Center for Business Research. Major areas of research interest: corporate finance, venture capital, international financial management.

Mail address: Helsinki School of Economics and Business Administration, P.O.Box 1210, 00101 Helsinki, Finland

Tel.: +358943138437

Email: ainamo@hkkk.fi 


\section{Introduction $^{5}$}

Most of the recent interest in corporate governance has focused on mature industrial economies where relatively efficient financial markets are the norm (Shleifer/ Vishny 1995; Mayerm 1996). These economies have well-understood legal standards and frameworks that ensure large flows of financial capital to firms, and ultimately repatriation of profits to the providers of that capital (Shleifer/ Vishny 1996). Alternatively, if profits are not forthcoming, systems are in place that enable owners to shut down a firm's operations and split up the residual assets in a well-defined way.

We believe that an equal degree of interest in corporate governance should be focused on developing economies, where there are no proven laws, regulations or practices. A large portion of global output resides in economies where welldeveloped and effective legal systems are only a pleasant thought (Garten, 1997). Consider the re-liberalised transition countries of the former Soviet and Comecon bloc, which must now overhaul their remaining outdated economic and social structures and make the transition into the capitalist system. Many of these countries have not only a recent socialist past but also a distant capitalist past, traces of which both remain. The most ready examples of these is "Central Eastern Europe" that is: the Baltic States, the Czech Republic, Hungary, Poland, Slovakia, and Slovenia.

There is the potential for the above economies in transition from a socialist system back to a market-driven to use their distant capitalist heritage, reconstruct old institutions, and grow in a way that foreshadows changes in more slowly moving economies that have never been capitalist. These economies have potential to develop more rapidly than mature Western economies which have already reached their maturity, and to catch up with them. The interest in corporate governance is thus perhaps best placed in such countries as those of Central Eastern Europe.

We use the Baltic States to describe and analyse how transition economies, through a process of economic development and social transformation, develop a system of corporate governance. Our findings include that, after privatisation, decreases in foreign investment and international organisation aid make it more difficult for the insider elite of local entrepreneurs and administrators to increase their wealth in the same way as before. They will be willing to increase their wealth in new ways and to secure their existing wealth by building foundations for corporate governance. This foundation, in turn, will be a platform for local demands for mechanisms that will strengthen the foundation and provide an improved platform for further demands.

5 The authors gratefully aknowledge helpful comments from Maija Vahanakki, Risto Tainio, Matti Pohjola, Riitta Kosonen and Marie-Laure Djelic. 


\section{Corporate governance and economic development}

Corporate governance can be defined as the structure that keeps management from pursuing its own goals at the expense of owners and other stakeholders. It rewards managers that generate value for stakeholders, and punishes those who decide to pursue their own objectives (Holmström/ Tirole 1989:86). There are many mechanisms through which mature industrial economies organise the relations between firms and stakeholders. Besides laws, regulations and legal interpretation that support the raising and disposition of financial support economic policies, countries also depend on a collective effort of industrial practices, government policies, technical and scientific institutions, national or regional education systems, cultural traditions, and many other institutions (Freeman 1995).

These mechanisms are altered through political processes particular to the local social and political climate (Shleifer/ Vishny 1996:3). The net result of good corporate governance are firms which can discriminate between good and bad projects, reward innovation, and punish behaviour which is not consistent with the wishes of its dominant stakeholders. In such a system, while each stakeholder has the right to influence the operations of the firm, the manifestation of these rights, and thus their strength, differ. For example, shareholders receive dividends because they can vote out the directors who fail to generate investment value. Creditors are paid interest because they have the power to repossess collateral.

In addition to motivating managers to excel, a good system of corporate governance supports the strategic long-term goals of both individual firms and the economy as a whole (Holmström/ Tirole 1989:87). It puts demand on managers to develop expertise relevant to the firm and its owners. Input from 'outsider' financiers forces 'insider' managers to make efficient strategic decisions regarding the overall distribution of corporate wealth (Shleifer/ Vishny 1996:10). Thus, managers understand, for example, that choosing to leave a loss-making plant open to save jobs in the short run only worsens market realities for everyone in the long run (Earle/ Estrin 1995:7). Corporate governance is a system that channels investment to profitable opportunities on the front end of economic development, and supports the efficient exit of firms with inadequate opportunities on the back end.

\section{Corporate governance in emerging economies}

The problem in emerging economies is that there is generally no well-defined tradition of corporate governance. Thus, the creation of support systems for good corporate governance is typically not one of the strengths of transition economies. Instead, in the absence of clear rightful owners, managers often acquire productive assets at below market prices. They may pass along at below market rates to consumers the products and services these assets generate. 
Nonetheless, this means there is little on-going pressure on managers to raise the assets' value through product and process innovation. Privatisations and corporate takeovers usually fail to produce value-added and well-being for anyone but for insider "robber barons" when the assets are akin to natural endowments or "free goods" that are not directly linked to issues of efficiency or productivity (Shleifer/ Vishny 1995:12).

Regardless of their nationality, managers are in principle equally skilled and rational, understanding their obligation to employees, creditors, investors and other stakeholders at a fundamental level. However, the degree to which a manager's action reflects these obligations is affected by the ability of the system to punish his or her breach of these obligations, as well as the ability of the economic system atlarge to reward good work within the system.

An economy usually accumulates its particular heritage of corporate governance typically only slowly. Following Porter (1990), economies and their systems of corporate governance tend to develop in four "stages". Development of wellfunctioning corporate governance systems normally accompany favourable economic progress (Holmes/ Johnson/ Kirkpatrick 1997).

According to Porter, if a developing country has any natural endowments, it can succeed in global competition by exploiting them, as long as they last and the costs to exploit them do not go up. If conditions change favourably, the economy enters the second stage of its development where there are investments in foreign manufacturing technology and methods. These are adapted and applied in the local setting, and ultimately improved upon. In Porter's third stage, the creation of innovation and technology that is new to the international marketplace incurs superior success in comparison to the factor-driven and investment-driven strategies. Finally, wealth derived from innovation provides resources to develop macro-stability and to fix the rules of the game (European Bank for Reconstruction and Development 1995).

Prudent laws and regulations instituted by the public sector are a critical enabler self-reinforcing growth (Porter 1990). Good working rules, laws, regulations and the financial sector support both the quality and quantity of investment and production decisions (EBRD 1995:3). In a virtuous circle, competition policy and investment-related legal structures can improve, firms move freely in and out of markets and industries, labour markets become more flexible, the capabilities of the creditors, firms and their managers grow, and the capital markets efficiently allocate capital (EBRD 1996:4). Wealth enables investments, innovation and a higher standard of living. On the other hand, Porter explains that the darker side of wealth is that it also degrades the cost-competitiveness of labour and technology. Maintaining the current level of affluence easily becomes more important than innovation. Investment accumulation and innovation may degenerate or cease altogether in order to promote short-term cost savings and profits. 
Innovation taking place in entrepreneurial organisations acts as an engine for the further creation of institutionalised legal, financial and technological structures, advancing the economy higher up on Porter's stages of economic development. A lack of innovation acts like brakes that are stuck, perpetually hindering forward motion. With a well-defined framework, firms in need of finance have the benefit of raising funds or other resources (Shleifer/Vishny 1996). Thus, the critical goal is to continually encourage innovations that can be applied to industry in order to maintain and increase innovation and success. This goal is the same in emerging economies as in mature industrial economies: to channel management in fruitful directions, and to guide the country's economic development to success (McKinsey Global Report 1996:4; Scott 1997:156).

\section{Corporate governance, innovation and entrepreneurship}

The link between a working system of corporate governance and innovation is entrepreneurship. Innovation is a flower that thrives in pockets of opportunity that have opened up opportunities for entrepreneurs to make innovative recombinations between pre-existing elements (Peterson 1988:65ff.). Manipulating barriers and social rewards linked to innovation through diverse economic as well as legal structures tends to be a more successful strategy in corporate governance than outright programming: innovations result from increases in demand for innovations and from opportunity to innovate.

Mature industrial economies can in the abstract be considered two-party systems where small entrepreneurial investors try to formulate a convincing alternative to a larger group of core investors, while the core investors collectively manage the lion's share of the existing investment. Entrepreneurial investors are revolutionary party who, through capital market prices, try to convince those at the ruling core that their alternative views are preferable. The system of corporate governance ideals is at a pivotal role because its mechanisms provide the alternatives at "election" times by which entrepreneurs can signal his or her firm's worth to the market.

A good system of corporate governance enables entrepreneurial persons who, for one reason or another, cannot develop their own ideas within a larger or more conventional organisational context to establish their own entrepreneurial organisations. Entrepreneurial organisations are thus typically breeding grounds for additional entrepreneurial spin-offs. They draw in entrepreneurially-inclined individuals who often end up leaving that organisation and establishing entrepreneurial organisations of their own. Actions of entrepreneurs thus lead to solutions that produce complex chains of spin-offs and subsequent innovations. One innovation solves a problem in a sector of the industry but disrupts other parts of the productive process, triggering a self-reinforcing process.

Thus, the objective in corporate governance is commonly to promote regulations that govern ownership and control structures between managers and investors in 
a way that encourages entrepreneurship and innovation in the economy. The system fosters competition by eliminating unnecessary rules of the game that raise barriers to entry and overly protect existing players from new competition. Ideally, barriers to entry are sufficiently low to promote competition, while sufficiently high to reward investment in innovation.

In early stages of economies in transition, entrepreneurial firms act as vehicles that experiment, discover and demonstrate new sources of country-level competitive advantages. On the supply side, it is at first most rational for wealthseeking entrepreneurs in these economies to acquire new assets via "nonmarket" procedures. On the demand side, the collapse of the socialist system offers opportunities to market new products and services and are a key driver of entrepreneurship. In later stages of transition, the goal is that the supply and demand side can be exploited by more established local firms as well (EBRD 1995:v), according which ever of the two is more efficient.

Of course, a system that maintains such a dynamic balance is complex and cannot be installed all at once. Also, one needs to solve the most pressing problems first. Foreign investors and local outsiders are usually quite happy to wait out provided that, in time, a system by which owners, creditors and such other stakeholders as employees, government and communities can control management will emerge. They expect only that their investments are treated as fairly as possible in the meantime (EBRD 1996:4).

\section{Many paths to a good system}

Mature industrial economies have each developed unique frameworks that determine the strength and nature of the right of a particular stakeholder group to a return on its particular investment. In Anglo-American economies corporate governance is "capital-market based": shareholders typically actively enforce that they be provided a return on investment. Shareholders provide managers with significant, though not excessive equity stakes in their firm to align interests (Jensen/ Meckling 1976; Leland/ Pyle 1977). Consider how a United States-based money management firm's strategy:

"[We are] ... an activist money manager. We buy stock in publicly held corporations that meet two investment criteria. They must be (1) underperforming, in light of strong underlying values, and (2) susceptible to increased value through shareholder involvement. Once we have established our position, we approach company management and directors, with the goal of enhancing value for our clients and other shareholders (LENS corporate WWW site:www.lens-inc.com)."

A second Anglo-American enforcement mechanism is to build common understanding of the rules of the game between investors and management on the basis of rules of the game that are quite institutionalised in the global 
financial market. An example of such a rule is "Previous owners deserve a fair share of the rise in the value of a firm being taken over". Owners sell out, voting with their feet when management fails to follow the rules. Reports of financial analysts and investment bankers are some of the means by which rules are communicated to those managers who do not yet know them.

Anglo-American funds that operate in a less developed or immature economy tend to place demands on governments. They demand a reduction of the institutional risks for both domestic and foreign investors to the minimum possible level. The lever they use to improve stability and market-driven reform on managers and governments alike is drawn from the fact that their future flow of their investments responds to changes in the laws affecting investors' rights (Tainio 1997; Cardwell 1997:7). If Anglo-American investors observe that rules regarding bankruptcy and expropriation are not explicit and enforced, for example, they may bypass firms in that economy altogether. At a minimum, they will lower their valuation of firms due to the lower expected terminal value because they will make a discount for the costs of security mechanisms to protect their rights, even their safety (Shleifer/ Vishny 1996:18,29), and for the risks associated with having to enforce their rights through expensive and inefficient court procedures.

The Anglo-American model implies a closed-ended process towards global standards of corporate governance. Indeed, many competitive differences across borders are disappearing because of the pressure of globalising financial markets and institutional investment. Whether global investors are activist or indirect as to their methods, their rules of the game combine into a neat, credible and easily communicated package, the fundamentals of which parties to a global transaction have institutionalised so that any dispute can be settled peacefully outside the legal court. The model seems gradually to spread to all global markets where Anglo-American funds operate. Shareholders exert pressure directly or indirectly in the boardroom, forcing managers to comply with, or at least acknowledge shareholder initiatives.

In contrast to the Anglo-American model, however, corporate governance in Germany and the Nordic countries has remained primarily "creditor based". Banks in these economies are motivated to encourage their clients to invest in profitable projects, which in turn provides the banks with more business. ${ }^{6}$ As a third alternative the French system differs from both the Anglo-American and Northern European ones. It can be described as "management driven": professional, often education-based networks of managers are the key driver of investment and operating decision-making. Differences in how and why

6 Recent work by Kaplan (1995:35) may indicate that the tenure of executives at German firms have become increasingly sensitive to poor stock market performance but this does not mean the trend will spread to all firms in all countries. 
managers (insiders) and capital providers (outsiders) interact across all these three kinds of systems of corporate governance have remained.

Fourthly, consider Central Eastern Europe where decreases in socialist-era barriers to entry introduce large investments opportunities. Many socialist-era governance mechanisms remain and provide particularities of corporate governance. Thus, transition economies have systems of corporate governance that are emerging and currently unlike those of any of the three principal models. The direction they will follow in the future may take towards any or all of the three models. Each move towards any of the three models creates its own unique dynamics of innovation, wealth-generation and creative destruction, as well as its own unique productivity and qualitative outcomes (McKinsey Global Report 1996:4). Each intentional or emergent outcome impacts on the evolution of the system and, thus, on how firms within the system are and will be attractive for investment, invest, innovate, perform, and provide returns for their owners and other stakeholders.

Thus, the goal of developing a system of corporate governance remains singular: to develop a system that will efficiently arbitrate manager-stakeholder conflicts. Emerging economies have more than one alternative model of corporate governance to by which to achieve this balance (Shleifer/ Vishny 1995:12). There is a research gap as to the process by which any model is chosen in the first place, and how it is adapted to suit the local needs.

\section{Transformation of social and economic systems in the Baltic States}

A number of researchers have dedicated their efforts to China, Russia or Central Europe due to their size and political stature. From this perspective, at first glance, one might venture to say that the Baltic States, because of the small size of their economies and markets, are not the most interesting ones. However, we believe the Baltic States are interesting due to the rapid steps towards capitalism that their small size has allowed. These economies can be considered laboratory settings that may reveal future developments of larger and more slow-moving economies in transition. Thus, we began to collect data about the Baltic countries already in 1988, and intensified our search from the end of 1995, terminating this report's data collection in 1997. Of the three Baltic States, we have chosen to focus in particularly on Estonia, partially due to geography and language considerations, partially due to its small size and leading pace of reform and development.

For purposes of cross-referencing data, collection, analysis and interpretation in and about the three Baltic economies, we have used a number of methods: publiclyavailable economic statistics (EBRD 1995, 1996), interviews (as outsiders) with insider-participants (lawyers, legislators, financial analysts, 
consultants and public policy makers) as well as secondary evidence (articles in the popular press). While we believe the data presented here to be accurate readers should keep in mind that the data available on the Baltic States are probably less accurate than those available on Western economies.

\section{The Baltic States in context}

The three Baltic States of Estonia (1.5 Million inhabitants), Latvia (2.5 Million) and Lithuania (3.7 Million) share fragments of heritages of Germany, Poland, the Nordic countries (Sweden, Norway, Denmark, and Finland) and Russia/Soviet Union. Situated in between the European Union and Russia by the Eastern coast of Baltic Sea, the three Baltic States of Estonia, Latvia and Lithuania were in the middle ages intermittently and in various degrees part of the German-Danish "Hansa" trade empire, or the Polish and the Swedish empires. In the 19th century they were all three part of the Russian one. The complexity of the sources of Baltic heritage has produced an eclectic system of corporate governance, the decisions of which are sometimes quite difficult to predict $^{7}$. For example, in the 1920s and 1930s Western laws and regulations in the Baltic States where modeled to accord with the German legal system. Yet the independent was too short in duration for these legal systems to reach sufficient and solid accord with the German legal logic, there was simply no time for it to take hold.

The Soviet Union annexed all three Baltic States in the late 1930s. The Baltic States learned in partly unequal, partly common degrees to share the mental and legal structures the Soviet Union, few of which are directly compatible with those of mature industrial states. One reason why the Soviets chose to accentuate differences between the three Baltic States and severe their linkages, was to integrate them with the rest of the Soviet Union. Latvia was made to conform to the requirements of the Soviet Union for heavy industry. The building and manning of huge factories meant that Latvia became the most "Russianised" of the Baltic countries. Estonia, in contrast, functioned as an economic laboratory for the Soviet Union, and was thus a hotbed of innovation in such high-tech fields as military electronics. Both Estonia and Latvia ended up with substantial Russian minorities because of the demands for military and other nonendogenous know-how. Lithuania, by being allowed to retain a high dependence on agriculture as the main source of livelihood, was the only Baltic State to retain its cultural homogeneity under the command economic system during the Soviet Union.

7 In some respects, the state of the legal situation in the Baltic States resembles that of Russia. For interesting commonalities between the systems, see Shleifer and Vishny's review (Shleifer/ Vishny 1996:3, 9, 18, 20, 22, 29, 48, 55). 
Under Soviet rule, managers and public policy makers across the Baltic States learned that consumption and savings were "residuals", forced by central planners on the basis of quantitative targets to adjust to decisions about output and investment. These were kept at artificially high levels by free-market standards. Investment was not the result of surplus consumption and savings, but was itself the starting point (EBRD 1995:67).

With the toppling of the Russian empire in the October Revolution of 1992 all three states regained independence. Along with other traces of their distant and recent histories, managers and administrators retained many traces of Soviet business culture, which economic history has proved to be less than optimal. In interpreting any practice, law, regulation or policy, it is often difficult to decide to what underlying logic is the local logic most similar. There has been considerable recent progress in education in management, economics and law, and managers may be highly-educated by Central Eastern European standards. Yet local managers, public authorities and lawyers often still lack knowledge of the basics of modern management, law or finance. The Balts themselves, like the citizens of some other Central Eastern European countries (Soulsby/ Clark 1996), themselves do not consider this to be a problem but resort to "national pride". The Estonians are quick to remind a Finns, for example, that they have little to learn from them because, in the 1930s, Estonia was richer than Finland; Estonia then was superior in investment, innovation and wealth accumulation. Less consideration they give to the fact most of those investments are by now of little worth. Much of the most educated and the most cosmopolitan social class fled the country then, most of them never to return, or were purged under Stalin's rule. National wealth in that process was irreplaceably lost abroad or to the Soviets. Against learning from other nationalities than the Finns, there are other reasons.

Thus, in many legal cases, for example, Baltic laws and regulations are so badly out of date that they are next to useless in predicting the court decision for someone who is not an intricately acquainted with the insider elite of the local managers, administrators and court officials. When one is fortunate to find a law on a given topic, often it has never been tried in court in the particular Baltic country in question. Laws and regulations are often treated on an ad hoc basis. To fill in the gaps, with recent economic and legal-regulatory support from the European Union, new law and regulation have been copied one-off from a number of other countries or the European Commission without a clear reference. The representatives of the European Commission have in some cases introduced some laws, regulations and policies that are Pan-European but in others according to they have been educated and trained: typically in Britain, Denmark or Finland. 


\section{From controlled experiments to industrial decline 1985-1989}

The Baltic States had to develop from the 1930s until the 1980s a working relationship with the Soviet Union. On the other hand, the Baltic States were among the last entrants into the Union. In 1985 there were controlled Soviet experiments with the market mechanism in Estonia. Estonia was chosen because of its historical proximity to capitalism. The experiments were in the service sector reforms; individual entrepreneurs were also encouraged in handicrafts production. The Soviets decided to base many of the pan-Soviet Union experiments before 1987 on the Estonian experience. (Mygind 1995b:210ff.). Thus, especially Estonia was in principle relatively well-placed for Pan-Soviet economic experiments and subsequent reform.

In 1987, economic reform was started by Gorbatchev on a Pan-Soviet scale. Throughout, the Pan-Soviet reform failed drastically. From 1987, the Soviet industrial value chains on both supply and demand sides that had dominated for five decades began to break down, new ones to replace them did not instantly surface, and there was serious industrial decline. To cope, Estonia introduced a 1989 Law on Economic Autonomy from the Soviet Union - at a time when it was still a Soviet republic (EBRD 1995:41). It also introduced a Law on (private) Enterprises. However, save a few joint ventures, such as the fish refinery joint venture "Esva" between the Estonian government and a Finnish company, Baltic policy makers did not quickly seize the opportunity offered by perestroika and take their destiny into their own hands. Restructuring of the complex Soviet industrial production and distribution systems was simply an awesome task.

Most of the individuals, institutions and governments in the collapsing Soviet bloc ran out of money at the same time, which meant that getting paid for delivery to a trading partner from the times that the Soviet Union had been a working system was difficult if not unlikely. The situation was made worse by the fact that the Soviet industrial system had during its heyday developed its own industrial standards, which meant that the systems of production and consumption of the post-Soviet bloc were mostly incompatible with those of their Western trading partners. Firstly, a lack of technology that conformed to Western standards kept industrial-scale volumes from being reached. Secondly, most Baltic firms (and all governments) had no history of being market responsive. Finally, the Baltic States lacked endogenous economic demand for their new consumer products. There was simply not enough affluence within the Baltic States to create any meaningful scale of new industrial production. Thus, not only remaining Soviet industrial ideological but also material structures slowed movement towards capitalism.

Yet, with independence, there was little or no scope to build up critical volume comparable to that of socialist times, on the basis of which volume expansion through internationalisation could then take place. There were difficulties in 
both the export of goods from the Baltic States and import of industrial goods into them. Industrial and agricultural production fell.

Despite the clear crisis and the new laws that sought to address, it nonetheless the Balts many years to move from discussing how to transform their industry to actively making any clear choices as what to do. Success was now measured fundamentally differently from that in centrally planned times. Firstly, they had many Soviet-time experiments to discuss and reassess. Secondly, Estonia and Latvia were split over two ideological regimes. On the one hand, an "economic" or technocratic regime favoured the direct sale of firms to managers and government officials who could, if needed, secure foreign investment capital. On the other hand, a "political" or nationalistic regime favoured restitution of property to 1930s owners and the distribution of vouchers; this regime feared that direct sales would favour an insider elite who connected to the former nomenclature because they had the most capital, still controlled the flow of information and had the right personal networks (Mygind 1995b:216,228).

\section{From turbulence to beginning of transformation 1990 - 1992}

While regimes discussed and reassessed the situation, the standard of living dropped across the Baltic States, (see Appendix 1 for GDP growth in Estonia, Latvia and Lithuania from 1989 to 1996). This drop was made worse by a lack of welfare and social security systems to buffer structural economic disturbances such as growing levels of unemployment. There was appearance of social unrest and unhappiness with the large Russian populace, whose preferential Soviet-era position was quickly eroded and turned around.

In this situation, Latvia, too, drafted in 1990 a Law on Joint-Stock Companies, comparable to the Estonian 1989 Law on Enterprises. Yet, like Estonia, Latvia stayed undecided on whether to opt for the economic-technocratic solution or the political-nationalist one.

Lithuania chose vouchers as its main policy of privatisation (Mygind 1995b:225). Thanks to this clear choice, it had initially the fastest privatisation program of the three Baltic States (Mygind 1995b:276). The primary reason for this speed and clarity of decision making was that the danger of giving away Lithuanian property to Russians was small because Lithuania's population was ethnically homogenous (read: non-Russian). The parliament election took place around the time of the August 1991 coup in Moscow. This crisis period strengthened the traditional egalitarian bias of Lithuanian culture. Voucher privatisation was well suited for privatising land and agriculture. With economic hardship and unemployment in the cities, moving citizens to make a living working their land had the promise of having a socially stabilising effect, since land provided employment as well as a protective element against inflation. Unfortunately, Lithuania's Law of Enterprises was completed as late as 1992 (ibid.:239). With these kinds of (pro-agriculture, anti-business) political goals 
and action, the introduction of foreign ownership of Lithuanian companies was effectively forestalled until as late as 1994 (Mygind 1995b:225ff.).

\section{Individuals as the source of change}

At the same time, some Baltic individuals had sufficient disposable income to readily pay for imported consumer goods. Soviet systems of consumption were technologically noncomplex and they could readily transform their life styles towards Western ones: there were few shifting costs from the life style of the Homo Sovietucus.

Some of these individuals were also entrepreneurially inclined. Especially Estonian entrepreneurs took a part of their disposable income in a strategy to "buy low" into the accumulated base of Soviet investments in the heavy-metal industries and "sell high" to the West. The collapsing Soviet Union provided such opportunities for simple arbitrage and economic growth. Thus, Estonia became a route by which Russian raw materials were exported to the West ("smuggled" might be an equally appropriate expression, since it took some time before proper border controls between the newly re-independent Estonia and Russia were instituted). In 1991, due to Estonia's heroic improvements in its trade balance and exports (see Appendix 2 for Estonia's trade balance and other selected measures of economic performance in 1991), there was some hope internationally that the Baltic States would retain their position within the Russia as the gateway to the West, while simultaneously becoming spectacular success stories of transition.

Latvia was quick to try to copy Estonia's arbitrage strategy (with some but not comparable success). Lithuania was happy to retain its dependence on agricultural products even though its markets had largely vanished with the collapse of the Soviet Union and Comecon.

Unfortunately for Estonia and Latvia, 1991 was also the year that Estonia, Latvia and Lithuania formally regained their independence. Already the next year, the Baltic States would experience in dramatic fashion the transition from a centrally planned economy to a market-driven in 1992 (see again Appendix 1). The Russian economy began to develop new export routes, becoming more directly linked to the West, bypassing the Baltic States altogether. Thus, Russian trade was a disappointment as to its ability to fuel economic development.

\section{Transformation begins in Estonia}

Estonia took the lead in economic transition among the Baltic States by making large-scale foreign investment possible (Mygind 1995b:231). Its chosen principle became privatisation through direct large-scale privatisation of its heavy industry (EBRD 1995:25). Small-scale privatisation had already started a year earlier (Terk 1995:75f.). 
Estonians soon began to pride themselves on their speedy transition towards a market economy. They established themselves a government agency for privatisation. Quick fortunes were by many in Estonia at that time. However, in the excitement and boom, inexperienced bank managers gave out loans indiscriminately. In many cases loans in new or privatised firms did not go into funding industrial projects but non-industrial investments that offered high rewards for high risks: real-estate arbitrage and adventurous play in the emerging financial markets. Also, many of the loans given to firms ended up funding managers' private consumption. The net result of these developments was a banking crisis in Estonia. ${ }^{8}$ The Estonian Bank refused to intervene; remaining banks across the Baltics, at least for a while, learned to be conservative and demand proper financial or real guarantees.

\section{From own currency to a threat of crisis 1993 - 1997}

On the whole, the national innovation system in Estonia was still characterised by a lack of disposable income, which made funding innovation and movement into new products and markets difficult. This could have been seen as a reason for concern in a mature industrial economy.

\section{Own currency and ambitious plans}

However, the emerging Baltic economies had momentum. Their citizens were in general more highly educated than those in other transition economies. The standard of living was also low; that is, labour was cost competitive. Foreign and local firms saw that Western technological and managerial resources could be imported into the Baltic States and adapted to local circumstances (EBRD 1996:17). In 1993, Estonia introduced its currency: now there was a fairly convertible foundation for foreign investment into Estonia. Latvia soon followed.

As long as the substantial gap prevailed between potentially high productivity (because of a highly educated work force) and low labour cost, there was also potential by investments to further raise productivity (EBRD 1996:17). The Estonians engaged in seminal talk of inviting foreign and local high-tech electronics industry to set up in Estonia. Several assembly plants for electronics products were set up, of which Finnish-owned Elcoteq, situated in Tallinn,

8 One of the authors personally remembers a friend whom he met in 1993 who ran a furniture retail shop in Estonia and phoned every day to the central bank to inquire which bank was the least likely to go bankrupt that day: this was a time when uncertainty about the process of economic transition was still extremely high. He was sure that neither the central bank nor government would bail out the banks, companies or depositors in the event of a bankruptcy: (His certainty was reasonably well founded: in 1994 the government rescued only one bank, the Social Bank). 
Estonia, was to develop into the largest exporter from the Baltic States. Telecom Finland invested in Estonian telecommunications projects and similar ones in the other two Baltic States as well. The new situation was beginning to resemble an industrial free-market economy.

Simultaneously, Baltic policy makers became increasingly willing to politically participate in European integration. They found economic aid to their countries can make a difference. Germany, Denmark, Norway, Sweden and Finland supported the Baltic States in the higher education of economics and law to teach the conventional wisdom of market economics, as well as legal frameworks by which to balance the interests of various economic stakeholders. Such foreign contributions were accepted from the Baltic perspective on the premise that the Western world was compensating the Baltic States for using them as bargaining chips with the Soviets in the 1930s. The Baltic States would benefit from overt economic subsidies from the European Commission and other international organisations.

Indeed, with the idea of speeding and supporting transition through trickle-down effects in the economy, the European Commission, the Nordic Council, the Nordic Investment Bank (NIB) and the European Band of Reconstruction and Development (EBRD) began to flood the Baltic States with investment.

The European Commission's aimed to funnel financial aid into infrastructure, developing new industrial sectors or improving the old, such as the electronics industry in Estonia. The most imminent overall effect of international aid was that banks financed those "core investors" (Terk 1995:80) who had by this time created seed money for themselves through simple arbitrage and non-industrial services financed by bank loans (Mygind 1995b:219). These investors had learned through experience the immediate and positive effect of financial shorttermism but not of industrial long-termism. Thus, in practice, it can be said that the old Soviet planning centres were replaced with new Western planning centres, a decision-making culture to which the Estonians readily adapted. Inexperienced bank managers in many instances were again funding projects indiscriminately. Available funds were not channelled into industrial projects but into real-estate arbitrage and adventurous plays on the emerging financial markets.

\section{Privatisation in motion}

As a result of developments that had been on the political agenda since 1990, Estonia introduced vouchers in 1992 (Mygind 1995b:245). However, by this time, the effect of the vouchers proved marginal. First, the protracted political discussion between the nationalistic and technocratic regimes before the introduction of the vouchers had resulted in a compromise that voucher use was limited to privatisation of housing and land. Second, by the time the applicability of vouchers was extended to unprivatised state companies the next 
year, there were few companies against the shares of which they could be exchanged (Mygind 1995b:218). Vouchers were soon traded at below their nominal value (Terk 1995:78, 85, 92).

Meanwhile, encouraged by success with Estonia's privatisation policy, and undeterred by its problems, Latvia's privatisation policy followed Estonia's as regards large-scale privatisation and vouchers (Mygind 1995b:220ff.,260ff.), even if public debate still carried on as if there would have been a balance between the nationalistic and the technocratic regimes.

According to the EBRD, Estonia was in 1995 third in per capita foreign direct investment of all the economies that were emerging from behind the iron curtain, trailing only Hungary and the Czech Republic (EBRD 1996:12). Estonians naturally proudly pointed to this track record of attracting foreign direct investment. With foreign direct investment came high currency inflows, acting as an engine for growth in the Estonian real economy. Matched with a rising desire of Estonians to hold local currency (kroons), the money flows financed an expansion in consumption and investment (EBRD 1996:13).

The Baltic States as a whole experienced a boom in their financial markets in 1995 and 1996. As the financial markets grew, more and more people were employed in that sector, coming to share in the sector's exceptional profits. With the potential for easy profits, the relative significance of investments into industrial production and innovation declined.

\section{Economic slowdown, return of nationalistic resistance to change}

The next year, 1995, was one of bank crises in Latvia and Lithuania, similar to the one that Estonia experienced three years earlier. In Latvia the activities of more than a third of commercial banks were suspended in 1995, including those of Bank Baltija, which at the time was holding 30 percent of all deposits in the Latvian banking system (EBRD 1996:11). Unlike the Estonian central bank in 1992 and 1993, the Latvian and Lithuanian ones chose to intervene in their bank crises in 1995 and 1996 (EBRD 1995:41). Latvia spent the equivalent of 7 percent of its GDP on compensation to depositors. Learning from the cost of the Latvia's experience, the Lithuanian central bank soon halted the planned merger of the country's two largest banks. It had discovered from its analysis of the merger that the largest one was insolvent.

Besides Latvia and Lithuania, problems surfaced in Estonia, too. Economic progress was not really taking place, even though the standard of living (and wages) were on the rise. The process of transition to a fully functioning market economy had not even brought production back to its original level. The EBRD estimates that, still in 1995, the Estonian output gross domestic product was only 66 percent of its level in 1989. The corresponding figures in Latvia and 
Lithuania were 54 and 42 percent, respectively (see Appendix 2 for selected measures of economic performance in Estonia, Latvia and Lithuania).

Generally, Baltic success stories in terms of new industry remained few and isolated. There was little explicit attention to new product development, export markets or innovation in general. There were a lack of local financial clout or other capacities of bearing the risk of setting up innovation-based sustainable competitive advantages. Industrial structures continued to deteriorate because local produce went unsold. Western products flooded the Baltic markets.

Most of the manufacturing in the Baltic States in the Soviet times was not competitive against the standards of the market economy. Thus, also foreign investment into industrial assets mellowed.

But through thick and thin, public policy makers across the Baltic States sought to maintain the path of their economies toward being increasingly affluent (wealth-driven) nations. They remained, for the most part, happy to be dependent on simple arbitrage brought on by the still relatively low wage levels, foreign investment and foreign aid. There was no need to actively do anything. True, there was a need for a second phase of restructuring. The Baltic States required a more highly developed strategy than simple arbitrage; to experience a turnaround, and create new wealth through industrial innovation. But the previous phase had been funded from Germany and the Nordic countries. The second phase would be the responsibility of Western Europe in its entirety (Estonia and the European Union 1995).

Besides funds and expertise for restructuring, the European Union also provided the Baltic policy makers with a promise of career opportunities and positions. Civil servants were (and have remained) notoriously poorly paid in the Baltic States, which contributed to their readiness and willingness to reorient themselves towards joining the European Union. The policy makers put as their goal to join 2004 or thereabouts. There was thus atmosphere throughout the Baltic States that the transition was well under way; taking place rather controllably in all of the Baltic States and exceptionally well in Estonia in comparison to some formerly Soviet European states. Inflation in Estonia was 4 percent and the growth of GDP 22 percent (these figures were compared to those of Turkmenistan, which experienced inflation at 2500 percent and growth of GDP at 0 percent in 1995). The corresponding figures in Latvia were 20 and 1 percent; in Lithuania they were 30 and 3 percent.

On the other hand, national pride buffered that the Baltic States would have had to follow the same "rules of the game" as other economies. Estonian Prime Minister Tiit Vahi in 1996 said "Eesti Energia should not be privatised to companies in the ownership of foreign [Swedish or Finnish] governments because then the Estonian firms would not be privatised". That year, an international lawyer working in Tallinn we interviewed elaborated: 
"It has proven typical that businessmen from one or two countries are very much in fashion at a time, then later the very same country or countries fall out of fashion. First it was Finland that was in fashion, then the United Kingdom. Now especially the United States is highly regarded as a source of investors, and Norway and Italy are very popular, too. There is a specific evolution in these passing fashions. Often it is when a businessman from a previously relatively unknown country comes and makes one acquisition, this positively impacts on the whole country image. But when many businessmen from that same country have come, their country of origin begins to represent for the Estonians imperialist exploitation, instead of making a contribution. Finns, for example where among the first to make investments in Estonians. Now the prices Finns paid for buildings, factories or assets in 1992 or 1993 are compared to the prices these assets would command today: a prime example is the Viru Hotel, which was acquired by a Finnish firm in 1994 and in very bad condition. [Now that it has been renovated and running smoothly] Finns are accused of exploiting the Estonians... Sometimes Estonian insiders replace sound judgement with nationalism. The Finns and Swedes were first movers in investing into the Baltic countries. This is now seen as a detriment for firms coming from those countries."

Threat of a crisis

Meanwhile, the economic situation worsened. The Baltic States, especially Estonia, began to experience rising wage levels, and to catch up with leading Western countries in terms of living standards and endogenous consumer demand. There was also seminal introduction of elementary welfare systems in Baltic States. In Latvia, fundamental pension reform was introduced that linked benefits more closely to lifetime contributions than before (EBRD 1996:8). The end result of these systems was also that they made Baltic labour to a large extent uncompetitive in global industrial competition.

In Estonia, there emerged in 1996 awareness that things were not progressing positively (Hinta- ja palkkatiedote 1996). Vahur Kraft, president of the Bank of Estonia, expressed concern over the lower-than-expected economic growth of Estonia (Aripaev, September 12, 1996). GDP growth of only 1-2 percent per annum and poor export performance created problems for the country's economic future. The currency board system of Estonia has meant that inflation has not allowed to be reflected in the value of the Estonian kroon. Amplified by the recent past history of large inflows (as measured, at least, by per capita) of foreign capital, this meant that production inside Estonia, for the most part, became uncompetitive in 1996. This is a key issue since individual firms, not the government, are to a large extent the ones who have been currently responsible for importing into Estonia technological and managerial know-how. With national uncompetitiveness, Estonia's direct foreign investments in 1996 fell below that of 1995 (Note that foreign direct investments to Estonia in 1995 were 
already below the level of 1994; see Appendix 2). These remarks caused speculation over Estonia's future development outside Estonia, given the small size of the economy. The Economist suggested that the Baltic States let their currencies float.

Estonian measures of national competitiveness such as trade balance and unemployment continued to deteriorate in 1997, showing weak signals of a crisis in). The Tallinn Stock Exchange crashed to less than half of its value. It was considered possible Latvia and Lithuania, with their larger populations and slower pace of transformation, would follow with time lags. Aid from the European Commission and other international organisations was not growing. Baltic policy makers discussed introducing selective deregulation, including in agriculture. However, a counter development had been in the making for some time already (see below).

\section{The emergence of corporate governance 1995 -}

However, a parallel process started in 1995 which promises to raise the Baltic States out of the peril. Like most developments in the region, this too has been led by the Estonians, but is spreading to other Baltic States, too, through among other things, growing cross-border trade between the Baltic States themselves. At the end of 1996, Latvia accounted for 10 percent and Lithuania for 7 percent of Estonia's exports, setting a new record. ${ }^{9}$ While there was still a lack of macroeconomic stability and social mechanisms in the Baltic States, microeconomic stability, a working business code, and rules of the game began to appear.

\section{A Pan-Baltic creditor - a stabilising force}

First, there emerged a stabilising factor that contributed to the emergence of corporate governance across the Baltic States (see brief case study, below):

A key shaper of the Baltic corporate governance and economy has been Hansabank, an Estonian bank that has emerged as the leading commercial bank in the Baltic States. It developed in a very short time in the 1990s into one of the area's leading banks by having diversified early on in related industries internationally. Many factors, including its status as a first mover, its ownership structure, its large size by Baltic standards, its commitment to the local market,

9 Latvia was third among Estonia's trading partner with 10 percent, with other trading partners being Russia (19 percent), Finland (14), Sweden (10) and Germany (9). In imports Latvia was not among the four leading counties (the share of Finland was 30 percent, followed by Russia's 12, Germany's 10 and Sweden's 8 percent (Aripaev, September 6 1996). Latvian trade and Lithuanian trade pan-Baltic was of roughly equal proportions but otherwise more with Russia and Germany and less with Finland. 
and its close relations with domestic institutions ("nomenclature") improved its operational capability in comparison to its domestic rivals.

Despite consistent initial losses in the early 1990s, Hansabank initiated an ambitious program of growth, endeavouring to become a generalist bank services provider. It diversified its portfolio, entering such new fields as investment banking, money management, real estate, and loans. Hansabank's ownership structure was perhaps more balanced and diversified than of its rivals. Hansabank's historical rivals were state-owned, banks owned by other firms, foreign-owned, or family-owned, whose capacity for quick and aggressive strategic change was considerably less than that of Hansabank. It was listed on the Helsinki Stock Exchange in 1994, signalling to investors that it was committed to developing stringent corporate governance systems.

Despite being nationally dominant, Hansabank long remained a small pioneering firm from an international perspective. It could be unnoticed by its rivals when it took advantage of the new business opportunities in real estate. Hansabank's strategy was to take risks on the shape of future regulations. At the same time, it defeated rival private firms that attempted a similar strategy to its own, using its close relationships with the key actors at the core of the local economy as a platform for penetrating the other Baltic markets.

Hansabank's stakeholders were in a pivotal position in establishing the Tallinn Stock Exchange. Hansabank's share price skyrocketed on the Tallinn and Helsinki stock exchanges between 1995 and 1997, with many-fold increases in value in a matter of only a few years. The phenomenal growth in Hansabank's sales, profits and share prices stabilised in 1997 when the Tallinn Stock Exchange as a whole came down amidst growing fears of devaluation of the Estonian kroon. Yet by this time Hansabank was firmly established itself as a key player in the Baltic States. In contrast to the short-termism of the stock exchange, it provided a stabilising force, having the resources to diversify both by hedging and by making multiple bets as to the direction of the future.

\section{A stock exchange - a working business code}

Already towards the end of 1995 it became apparent that the Baltic States had jumped from a factor and investment-driven stages into wealth-driven stage, without experiencing the innovation-driven stage in between. Foreign aid and foreign real investment were fast decreasing. In 1995, the Estonians decided to open the Tallinn Stock Exchange, which opened a year later. One of the underlying reasons for the stock exchange was to attract new foreign financial investment, as real investment was slowing down.

With this set of priorities (and not for developing commerce or industry, as such), the Estonian 1989 Law of Enterprises was revised in 1995 (see Table 1). The names of different kinds of enterprises and businesses (1989 "aktsiaselts", 
and 1995 "osauhing" and "aktsiaselts") cause confusion. But otherwise, the 1995 Business Code repairs three major problems present in the 1989 Law on Enterprises.

The first problem with the 1989 Law on Enterprises was that it allowed any board member (i.e. manager), whether resident in Estonia or not, to alone represent the company in business matters. In practice, privatisation procedures meant that it was better to have at least one resident. He or she was allowed to pursue personal interests at the expense of other stakeholders. The interests of owners, for example, were not necessarily in tandem with the manager's personal (this is corporate governance's classic "principal-agent" problem). The latitude present in the 1989 Law on Enterprise presented obvious control problems, freeing managers to make deals that furthered their own personal interests at the expense of the firm. In the 1995 Business Code, the presentation rights are much more consistent with those in other Western countries. There is a working internal manager group within the company (the "Board of Directors") and a external Board representing owners (the "Supervisory Council"). Note that local and foreign owners are now given almost equal rights: the Chairman of the Board may be a foreigner, and half of the board members may be foreigners as well.

A second problem of the 1989 Law on Enterprises was the absence of concrete auditing requirements. The above principal-agent problem was amplified because managers had no pressure to account what they had done. It was very difficult to indict a manager of embezzlement. The new 1995 Business Code improved the situation. Public limited liability companies that continue to attract foreign investment almost without exception use services of international auditing companies such as Price Waterhouse and KPMG.

Finally, in the 1989 Law on Enterprises the minimum share capital of EEK 300 (about USD 30) was too low. All firms, risky or safe, were pooled together in one category. This made it very costly for customers and financiers to make initial screens as to the quality of the company, and reduced the efficiency of the system. With the 1995 Business Code, the division of joint stock companies into public versus private limited liability companies provides major firms of international potential an easy way to detach themselves from the pool of minor ones. Even the share capital needed to attain the private limited liability status roots out a large mass of pretenders.

\section{Precedent cases - rules of the game}

Favourable developments in company law are necessary, but not sufficient grounds for transition. For a long time, any court rulings in the Baltic States were to a large extent arbitrary because of a lack of laws. Courts in Estonia in 1996 also lacked human and administrative resources to handle complex 
commercial disputes (EBRD 1995:111). For example, consider the following brief case study (below):

Esva, the joint-venture fishing refinery established during the time when the Soviet Union still existed by Estrobrom, a fish refinery owned by the Soviet Republic of Estonia and by Valio, the Finnish firm, proved early on not to be sufficiently profitable to repay two Finnish banks and one Russo-German banks. To keep the creditors from driving the operation into bankruptcy, the minister of financial affairs of the now independent Estonian Republic, which had inherited its property from the Soviet Republic of Estonia, gave a guarantee on behalf of the state that the loans (USD 40 Million) would be repaid. In this guarantee, fishing vessels in Esva's (renamed as Ookean) ownership became security for the loans. 
Table 1: The 1989 Law on Enterprises and the 1995 Business Code

\begin{tabular}{|c|c|c|}
\hline \multirow{2}{*}{$\begin{array}{l}\text { 1989 LAW ON ENTERPRISES } \\
\text { The Joint Stock Company } \\
\text { ("Aktsiaselts" or "AS") }\end{array}$} & \multicolumn{2}{|c|}{1995 BUSINESS CODE } \\
\hline & $\begin{array}{l}\text { Private limited liability } \\
\text { company ("Osauhing" or } \\
\text { "OU") }\end{array}$ & $\begin{array}{l}\text { Public limited liability } \\
\text { company ("Aktsiaselts" or } \\
\text { "AS") }\end{array}$ \\
\hline valid until 1 September 1997 & $\begin{array}{l}\text { Replaced } 1989 \text { Law fully } \\
\text { after a transition period } \\
\text { (i.e. on } 1 \text { Sept 1997) }\end{array}$ & $\begin{array}{l}\text { Replaced } 1989 \text { Law fully } \\
\text { after a transition period } \\
\text { (i.e. on } 1 \text { Sept 1997) }\end{array}$ \\
\hline $\begin{array}{l}\text { There may be a Managing } \\
\text { Director (in practice there } \\
\text { usually is not) }\end{array}$ & $\begin{array}{l}\text { There may be a Managing } \\
\text { Director (in practice there } \\
\text { usually is none) }\end{array}$ & $\begin{array}{l}\text { There may be a Managing } \\
\text { Director (in practice there } \\
\text { usually is none) }\end{array}$ \\
\hline $\begin{array}{l}\text { There must be a Board of } \\
\text { Directors with at least one } \\
\text { member }\end{array}$ & $\begin{array}{l}\text { There must be an executive } \\
\text { Board of Directors with } \\
\text { at least one member }\end{array}$ & $\begin{array}{l}\text { There must be an executive } \\
\text { Board of Directors with } \\
\text { at least one member }\end{array}$ \\
\hline $\begin{array}{l}\text { Every Board member has the } \\
\text { role to alone represent the firm, } \\
\text { as would a Managing Director }\end{array}$ & $\begin{array}{l}\text { Chairman of the Board has } \\
\text { the right alone represent the } \\
\text { firm }\end{array}$ & $\begin{array}{l}\text { Chairman of the Board } \\
\text { has the role to alone } \\
\text { represent the firm }\end{array}$ \\
\hline \multirow[t]{4}{*}{$\begin{array}{l}\text { Chairman of the Board may be } \\
\text { foreign or Estonian }\end{array}$} & $\begin{array}{l}\text { Chairman of the Board may } \\
\text { be a foreigner. However, at } \\
\text { least half of the Board } \\
\text { members must be } \\
\text { residents in Estonia }\end{array}$ & $\begin{array}{l}\text { Chairman of the Board may } \\
\text { be a foreigner. However, at } \\
\text { least half of the Board } \\
\text { members must be } \\
\text { residents in Estonia }\end{array}$ \\
\hline & & \begin{tabular}{|l|} 
The Board of Directors is \\
subordinated to a \\
Supervisory Council which \\
in principle controls strategid \\
planning, approving \\
major investments, etc \\
\end{tabular} \\
\hline & & \begin{tabular}{|l|} 
A Supervisory Council has \\
at least three members, \\
none of whom need to be \\
Estonian residents. \\
\end{tabular} \\
\hline & & $\begin{array}{l}\text { All Council members must } \\
\text { be different from members } \\
\text { of the Board of Directors }\end{array}$ \\
\hline $\begin{array}{l}\text { There is no requirement for } \\
\text { auditing }\end{array}$ & $\begin{array}{l}\text { There are some limited } \\
\text { requirements for auditing }\end{array}$ & $\begin{array}{l}\text { There is auditing } \\
\text { according to } \\
\text { international standards }\end{array}$ \\
\hline $\begin{array}{l}\text { Share capital minimum of EEK } \\
300 \text { (about USD 30) }\end{array}$ & $\begin{array}{l}\text { Share capital a minimum of } \\
\text { EEK } 40,000 \text { (in practice } \\
\text { below EEK } 400,000 \text { ) }\end{array}$ & Share capital EEK 400,000 \\
\hline $\begin{array}{l}\text { Roots of law are in Soviet 1980s } \\
\text { experiments }\end{array}$ & $\begin{array}{l}\text { Roots are Pan-European or } \\
\text { global }\end{array}$ & $\begin{array}{l}\text { Roots are Pan-European or } \\
\text { Global }\end{array}$ \\
\hline
\end{tabular}


Surprisingly, employees took in 1995 Ookean into bankruptcy for unpaid wages and salaries. The Estonian executor of the bankruptcy estate denied the validity of the state guarantee and the loan agreement, claiming that the Estonian government cannot stand for liabilities originally created under the Soviet rule, making a nationalist claim that the loans were originally taken during the time when Estonia was occupied by the Soviet Union, meaning that the state guarantees given by the Republic of Estonia during its independence were invalid. The Finnish and the Russo-German banks were not accepted as creditors of the bankruptcy estate. The first Estonian court ruling was in favour of the executor and to the detriment of the foreign creditors, disregarding the fact that the Estonian and Finnish governments have had throughout the legal process a mutual treaty of investment protection. Meanwhile, the executor was allowed to begin selling the shipping vessels to former workers of Ookean and the assets originally purchased with Western funds were thus appropriated by insiders. The legal case continues as an international arbitration process between the governments of Estonia and Finland over the content of their investment protection treaty.

While the above cannot be seen as a positive development, something positive clearly was afoot in 1997. Witness the three controversial incidents, below:

A low court judge in Tallinn was a first mover in refusing to be bribed by a lawyer for the defendant. The judge videotaped the lawyer's bribery attempt and used it as evidence for indictment. When the case was heard in low court the lawyer was released because the (different) judge ruled that a bribe is not a bribe if not accepted. The case also reached high court, but the case was dismissed and the lawyer freed there as well. The decision was that "no criminal deed has been committed" because, firstly, the "payment was not successful" and, secondly, the low court judge had "no right to videotape" the lawyer's bribery attempt. Paradoxically, the high court ordered that the lawyer be returned her money because no service had been rendered in return.

Mr. Tiit Vahi, the Estonian Prime Minister was challenged publicly that he had been involved in corruption when participating in the use of a legal loophole by which government and city officials had privatised apartments in the Old City of Tallinn to their families and friends. The total losses to the City of Tallinn were in the region of USD 40 Million (for comparison, consider that this is about ten times the value of the annual Estonia military budget). Because of unsurpassed controversy around the issue, Mr. Vahi had to resign. He and his friends were allowed to keep their apartments but when a new cabinet was formed by $\mathrm{Mr}$. Mart Siiman, he declared that from there onwards there would be "transparency in his cabinet".

The rule of thumb became that public controversy is the key driver of developing a foundation for system of corporate governance rather than any objective concerns of economy. Mr. Siiman included in his cabinet Mr. Villu Reiljan, who had been challenged that he had earlier misused of funds for environmental 
protection. Yet Mr. Siiman kept him in his cabine: "... accusations are not very strong, otherwise I would ask him to step down" (The Baltic Times, March 20, 1997).

Public controversies about rules of the game were in 1997 accelerated by a European Commission ("Agenda 2000") report that put forth the poor development of the legal framework of Estonia and its consistently poor relations with Russia as reasons which made it pass the threshold into further negotiations to join the European Union only barely.

Estonia was passed because it was the first-mover of the three countries, and the idea was that the development of Estonia might pull in its stream the other two Baltic States, which were not passed at this stage. Critics of the European Commission report were quick to point out that to Latvia and Lithuania maintained better relations with Russia than did Estonia, as well as that the report failure to pay attention to Latvia's and Lithuania's rapidly improving legislation, or Latvia's ability to have twice as much transit trade from and to Russia as Estonia. This awareness across Europe that the Baltic States are not one homogenous region with Estonia in the lead introduced healthy competition between the Baltic States. With improvements in both corporate governance and the competitive environment, the hope is that the Baltic States' industrial production will soon experience a turnaround, and create new wealth through industrial, instead of only appropriate and financial innovation. EBRD would thus be right in promoting the idea that profit-oriented investors should tap "productivity reserves" such as a large endowment of human capital in Baltic States (EBRD 1995:75).

\section{Conclusions}

Conventional American managerial textbooks and international reports assume a static or linear setting of open competition, efficient markets, good corporate governance and democracy, which all supposedly go hand-in-hand. But they seldom focus on tangible questions such as "For whom is a system of corporate governance 'good'?". This has been our aim. Based on our study of economic development, social transformation and corporate governance in the Baltic States we conclude with some dynamics that are generally not found in conventional textbooks or reports (Holmes/ Johnson/ Kirkpatrick 1997).

Thus, we have investigated developments in transition economies with both a recent socialist and a distant capitalist past. We have explored how economic development towards a mature industrial economy follows a systematic logic that perhaps can be managed, instead of only following a haphazard evolution. Note that we do not mean that the Baltic States would be somehow unique in the way their systems of corporate governance emerge. Quite the contrary. Given the large stakes placed by firms and international organisations in economies 
such as Hungary, the Czech Republic, Poland and Russia, predictions about how their systems emergence will resemble the system emergence of the now mature industrial economies will be valuable, however uncertain such predictions at this stage may be.

\section{Initial privatisation and early economic transition}

On one hand, we have found that in the Baltic States, in particular during the early stages of the transition, "national pride" or "nationalism" provided a pretext by which Baltic insiders successfully killed substantial valuable time before they allowed the transition any chances of becoming successful. Local entrepreneurially inclined individuals had favourable positions to appropriate natural-endowment or other material streams left over from the old system of central planning. The crumbling remains of the socialist institutional framework granted them with first-mover advantages to be "king of the hill" of the rising economy. Old Soviet-time administrators remaining in their place were quick to collude with the above entrepreneurs and to form an insider elite with them. Jointly, they privatised goods, as well as legal entities that contained assets accumulated through years of Soviet industrial investments. The seemingly bottomless availability of assets kept the game a plus-sum game for them. Exits by some foreign investors that became disillusioned were more than offset by new entrant investors who likewise could be exploited, as well as by growing expertise in exploiting the Soviets heritage. As for local outsiders that were not part of the small inside elite, these were too small in number to cause much commotion. Constant inflow of foreign investment provided all locals, even outsiders, with a source of general optimism that everything was possible.

In the process, some of the insiders learned quickly to disregard any requests by foreigner that there be clear "rules of the game". As long as new foreign investors entered with "me-too" investments and an inability to comprehend the 1989 Law on Enterprises, these insiders thus improved their situation. As long as no-one actively coerced the insider elite to embrace market-driven conditions, no systematic program to establish a system of corporate governance emerged. Insiders disregarded any requests as long as "free goods" from the socialist times or new similar inflows from abroad were available. The insiders were provided with possibilities to improve their competencies and practice with the investments of foreign or local outsiders who, in turn, were handicapped by limited information. Goals of insiders and thus differed from those of some outsiders who desired to introduce ideas about open competition, efficient markets and owner-manager relationships of international standards into the still relative insular Baltic States.

Generally, on the basis of our study, we propose that in the early stages of transition some locals in a transition economy desire that there are few rules of the game. They are the ones who are in the best situation to be the first investors, 
the first to get to choose how they allocate; the ones to more cheaply invest, actively participate in the dynamics of the emerging system, readily hear about new opportunities, and learn. The insider elite of insiders seeks to develop a degree of control of economic development, appropriating the proceeds to themselves. It protects its tightly-knit positions under the pretext of nationalist pride and nationalism to channel foreign investments and international aid in ways that benefit itself. It appropriates high both economic and social returns: others get to choose from what is left over.

\section{Post-privatisation transformation and corporate governance}

On the other hand, we have found that, before long, there were in the Baltic States less investments put into the pool of "free goods" than assets were taken out. But it was not easy for the insiders to understand that foreign investors can go and follow the development of some other economy if there is a prolonged time during which the high probability of extraordinary profits disappears. The realisation of such a scenario became more likely as prices of Baltic assets and labour went up, proper legal frameworks failed to appear, and incidents where local managers expropriate foreign investments recurred. However, the successful local insiders were much slower to learn any new rules of the game than to disregard old ones. Learning is never automatic, but requires tangible or first-hand experience. When foreigners began to abstain from investment and the European Commission and others began to write critical reports and analyses, freely available resources began to run out. That is when local insiders began to make the link between decreases in inflows of foreign investment and the need for foundations for corporate governance.

As a parallel development, many members of the insider elites had made themselves sufficiently wealthy and powerful as well as sufficiently diversified their business to begin to feel they needed corporate governance and transparency to protect themselves and their positions from the risk of being treated like an outsider. Thus, the two parallel trends of decreasing freely available goods and satisfactory levels of individual levels, which seemed at first only loosely coupled, led to closely interrelated outcomes that became integral part of the emerging system of corporate governance.

Firstly, the banking sector improved, building towards a creditor-based system where there is a local supplier of funds for innovation across the Baltic States. Secondly, in order for the insiders to make their items of wealth tradable, stock exchanges were established in Estonia and then across the Baltic States. The stock exchanges, in turn, spread ownership of assets and a working business code more widely in the population. Thirdly, public controversies over the interpretation of the rules of the game that would not only meet the requirements of the old insider elite, but also of other investors and stakeholders: owners, firms, institutions and individuals. The Estonian 1995 Business Code was a seed 
that began to transform the rules of the game by providing the foundations for the development of an international-standard system of corporate governance over many years, if not decades.

Generally, we propose that systems of corporate governance according to international standards surface on the basis of local - not international - needs. Before a system of corporate governance can emerge in a transition economy, there must local demand for the system. This demand comes about when locals learn to discriminate between socialist, capitalist and endogenous systems, as well as between outdated systems that have to be scrapped and ones that have to be retained because they are worth salvaging.

\section{Discussion}

On the basis of our study, we advise foreign investors in transition economies to clearly demonstrate to insiders that it is in their best interest to increase transparency and improve corporate governance. Foreign investors cannot directly affect the overall competitiveness of economies that are in the process of developing their system. An indirect step is to hire recently managers educated after the transition has begun ("new generations, new orientations"). Training of established managers may only be efficient when these have run out of socialist-era assets to freely appropriate, of new foreign assets, and of overly eager outsider entrants that pay for local investments into new assets. This situation makes them sensitive to arguments that they will lose something valuable if they do not co-operate, and gain something valuable if they do.

There are advantages to maintaining a broad network of contacts by which to signal to local partners "If we are not treated well, both we and our resources will go away". One can perhaps get the "most bang for their buck" by allowing the locals the possibility to discuss corporate governance in the name of national pride, nationalism, morals or ethics, instead of the need to protect the rights of foreign investors. Highlighting the significance of historic and national institutions that align the interests of various economic actors across borders and various stakeholders is one way to raise the chances of a success.

What has been said above for foreign investors is mostly valid for international organisations as well. However, some qualifications are in order. Perhaps interestingly, we find that decreases in, or threats to decrease, the amount of the foreign aid contribute to the local establishment of the foundations for good corporate governance more than do increases. Prolonged international support and subsidies hinder market responsiveness, the effectiveness that is the key to a modern economy. A clearly signalled phase-out of international support in the case of an economy in transition impacts positively on the emergence of corporate governance. Otherwise the need for "support from central planning" will never disappear. Only in the face of decreasing foreign aid is there a need for locals to compensate the decrease with new laws and regulations that are 
conducive to foreign investment. Thus, the timing of ending foreign aid rather than the timing of its beginning or its magnitude is crucial for founding corporate governance.

As for further research, there remains after this paper a need for further research in corporate governance in the Baltic States and in other Central and Eastern European economies. Given that the historical brush of the Baltic States with capitalism affords them the best chance at emerging quickly, the failure of these economies to instantly develop is a disturbing reminder of the difficulty of the task facing reformers in some other economies with a recent socialist past. Our findings may have more than European appeal. Research in and about Central and Eastern Europe can be reciprocally combined with research in and about Russia, as well as other emerging economies without a capitalist past. For example, consider that Chinese laws have recently been called "indistinguishable from administrative regulations and often either unwritten or not publicly available in written form." (Boisot 1994:27). The challenge is to describe the enactment of local and global systems in immature, emerging and developing economies, explaining the underlying economic and social processes.

\section{References}

Ainamo, A. (1997): The Evolution of the Finnish System of Innovation: The Contribution of Nokia, in: Fynes, B./ Ennis, S. (eds.): Competing from the Periphery: Core Issues in International Business. The Dryden Press.

Aripaev (1996): Central Banker concerned over economy, September 12, 1996.

Boisot, M. (1994): The challenge of governance in post-socialist enterprises, Routledge.

Cardwell, W. (1997): Foreign Investment and the Performance of Finnish Firms. A Stock Market Perspective, LTT Sarja B 135.

Earle, J.S./ Estrin, S. (1995): Privatization Versus Competition: Changing Enterprise Behavior in Russia, Working paper, first draft, Center for CIS and Middle Europe, London Business School.

EBRD European Bank for Reconstruction and Development (1995): Transition Report: Investment and Enterprise Development.

EBRD European Bank for Reconstruction and Development (1996): Transition Report Update.

Economist (1997) according to Helsingin Sanomat, 11.5.1997: The Baltic countries are to abandon their strong links to strong currencies.

Estonia and the European Union (1995): Preliminary Theses of Future Membership (1995): Republic of Estonia State Chancellery.,Tallinn 1995.

Freeman, C. (1995): The "National System of Innovation" in Historical Perspective, in: Cambridge Journal of Economics, Vol. 19, p. 524. 
Garten , J. (1997): Troubles ahead in emerging markets, in: Harvard Business Review, MayJune, pp. 38-50.

Hinta- ja palkkatiedote (1996): Real income in Estonia virtually unchanged.

Holmes, K./ Johnson, B./ Kirkpatrick, M. (1997) (Editors): 1997 Index of Economic Freedom, The Heritage Foundation.

Jensen, M./ Meckling, W. (1976): Theory of the firm: Managerial behavior, agency costs and ownership structure, in: Journal of Financial Economics, 3, pp. 305-360.

Kaplan, S.N. (1995): Corporate governance and incentives in German companies: Evidence for top executive turnover and firm performance, in: European Financial Management, Vol. 1, No. 1.

Leland, W./ Pyle, D (1977): Information asymmetries, financial structure and financial intermediation, in: Journal of Finance, 32:2, pp. 371-387.

Mayer, C. (1996): Corporate governance, competition and performance, OECD Economics Department Working Paper No. 164.

Mygind, N. (1995a): A Comparative Analysis of the Economic Transition in the Baltic Countries - Barriers, Strategies, Perspectives, in: Mygind, E. (ed.): Privatization and Financial Participation in the Baltic Countries, PFPB Project Midterm Results, Copenhagen Business School, pp. 69-92.

Mygind, N. (1995b): Privatization and Employee Ownership in the Baltic Countries-A Comparative Analysis of Conditions and Employment, in: Mygind, E. (ed.), Privatization and Financial Participation in the Baltic Countries, PFPB Project Midterm Results, Copenhagen Business School, pp. 69-92.

Peterson, R.A. (1988): Entrepreneurship and Organization, in Handbook of Organization Design.

Porter, M. (1990): The Competitive Advantage of Nations, The Free Press.

Holmström, B./ Tirole, J. (1989): The Theory of the Firm, in: Schmalensee, R./ Willig, R.D. (eds.): Handbook of Industrial Organization, Elsevier Science Publishers B.V., New York.

Schumpeter, J.A. (1934): The Theory of Economic Development, Harvard University Press, Mass.

Scott, B. (1997): How Do Economies Grow. Book review of 1997 Index of Economic Freedom, in: Harvard Business Review, May-June, pp. 156-164.

Shleifer, A./ Vishny, R. W. (1996): A survey of corporate governance, NBER Working Paper 5554, April.

Soulsby, A./ Clark, E. (1996): The Emergence of Post-Communist Management in the Czech Republic, in: Organization Studies, Special Issue: Managerial Learning in the Transformation of Eastern Europe, pp. 227-247.

Tainio, R. (1997): Organisational Responses to Radical Environmental Changes, 13th EGOS Colloquium, held at Budapest University of Economic Studies, July 3-5.

Terk, E. (1995): Employee-Ownership and the Political Debate in Estonia 1987-1994, in: Mygind, E. (ed.): Privatization and Financial Participation in the Baltic Countries, PFPB Project Midterm Results, Copenhagen Business School, pp. 69-92. 
The Baltic Times (1997): New Estonian PM Orders Diagnosis, March 20.

Appendix 1: Growth (real GDP) in the Baltic States

\begin{tabular}{|l|l|l|l|l|l|l|l|l|}
\hline & 1989 & 1990 & 1991 & 1992 & 1993 & 1994 & $\begin{array}{c}1995 \\
\text { Esti- } \\
\text { mate }\end{array}$ & $\begin{array}{c}1996 \\
\text { Projec- } \\
\text { tion }\end{array}$ \\
\hline Estonia & -1 & -8 & -11 & -14 & -7 & -3 & 4 & 6 \\
\hline Latvia & 7 & 3 & -8 & -35 & -15 & 2 & 1 & 1 \\
\hline Lithuania & 2 & -5 & -13 & -38 & -24 & 2 & 3 & 3 \\
\hline
\end{tabular}

Source: EBRD 1996, 22

Appendix 2: Selected measures of Estonia's Economic Performance

\begin{tabular}{|c|c|c|c|c|c|c|c|c|}
\hline & 1989 & 1990 & 1991 & 1992 & 1993 & 1994 & $\begin{array}{l}1995 \\
\text { Esti- } \\
\text { mate }\end{array}$ & $\begin{array}{c}1996 \\
\text { Projec- } \\
\text { tion }\end{array}$ \\
\hline & & & \multicolumn{3}{|c|}{ Percentage change } & & & \\
\hline \multirow[t]{2}{*}{ Consumer prices } & 6 & 34 & 211 & 1076 & 90 & 48 & 29 & 25 \\
\hline & & & \multicolumn{4}{|c|}{ (In millions of US dollars) } & & \\
\hline Trade balance & n.a. & -250 & 561 & -90 & -145 & 361 & 650 & n.a. \\
\hline Exports & n.a. & 1843 & 2822 & 461 & 812 & 1327 & 1850 & n.a. \\
\hline Imports & n.a. & 2093 & 2261 & 551 & 957 & 1688 & 2500 & n.a. \\
\hline $\begin{array}{l}\text { Foreign direct } \\
\text { investment }\end{array}$ & n.a. & n.a. & n.a. & n.a. & 162 & 214 & 192 & n.a. \\
\hline \multirow[t]{2}{*}{$\begin{array}{l}\text { Gross inter- } \\
\text { national reserves }\end{array}$} & n.a. & n.a. & n.a. & 4.5 & 4.8 & 3.3 & 2.8 & n.a. \\
\hline & & & \multicolumn{4}{|c|}{ (Percent of GDP) } & & \\
\hline $\begin{array}{l}\text { Share of industry } \\
\text { in GDP }\end{array}$ & n.a. & n.a. & 40 & 33 & 26 & 19 & 17 & N.A: \\
\hline
\end{tabular}

Source: EBRD 1996, p. 31

n.a. $=$ not available 
